\title{
Transnational Labour Governance: A Critical Review of Proposals for Linkage through the Lens of the Rana Plaza Collapse in Bangladesh
}

Zobaida Khan ${ }^{*}$

\begin{abstract}
Exploitative working conditions in the factories of developing countries like Bangladesh have fueled scholarly arguments for linking labour governance through trade/economic cooperation agreements/arrangements. This article argues that despite rich theoretical analyses of the structural form of these trade/economic-labour linkage mechanisms, less attention has been paid to the conceptualizations of "the social," which tend to be narrow. These conceptualizations yield a restrictive approach to labour governance, maintaining a sharp difference between fundamental and redistributive approaches to transnational labour law. This approach may focus only on workers engaged in exporting sectors; defend individualized, civil, and political rights; weaken the participation of non-state actors in factory monitoring; and accentuate voluntary forms of corporate responsibility. Referring to some of the challenges in the transnational governance mechanisms launched after the collapse of Rana Plaza, this article argues that it is necessary to consider the aggregate effects of labour deregulation and the distributional problems of labour.
\end{abstract}

Keywords: Transnational labour governance, rana plaza collapse, transnational safety initiatives, distributional problems of labour, neo-liberal labour deregulation

\section{Résumé}

La présence de conditions de travail abusives dans les usines de certains pays émergents, tels que le Bangladesh, ont alimenté les argumentaires scientifiques reliant la gouvernance du travail et les accords/arrangements de coopération commerciale et économique. Cet article soutient que, malgré de riches analyses théoriques sur la forme structurelle de ces mécanismes de maillage commercial et économique, une attention subsidiaire a été accordée aux conceptualisations du « social », qui tendent à être limitées. Ces conceptualisations aboutissent ainsi à une approche restrictive de la gouvernance du travail et maintiennent une nette différence entre les approches fondamentales et redistributives du droit transnational du travail. Cette approche peut se centrer uniquement sur les travailleurs engagés dans les secteurs exportateurs,

\footnotetext{
This article is a modified version of one of the chapters in my doctoral thesis. Zobaida Khan, "Trade, labour and sustainable development: An integrated perspective," DCL thesis, McGill University, 2017. Comments from my supervisor, Professor Adelle Blackett, enriched both the format and contents of the paper. A generous financial award from the Social Sciences and Humanities Research Council is gratefully acknowledged.
}

Canadian Journal of Law and Society / Revue Canadienne Droit et Société, 2018, Volume 33, no. 2, pp. 177-197. doi:10.1017/cls.2018.12 
défendre des droits individuels, civils et politiques, affaiblir la participation des acteurs non étatiques dans le contrôle des usines et accentuer des formes volontaires de responsabilité des entreprises. En référant à certains des défis relatifs aux mécanismes de gouvernance transnationaux lancés à la suite de l'effondrement de Rana Plaza, cet article soutient qu'il est nécessaire de considérer les effets globaux de la dérèglementation du travail et les problèmes de répartition du travail.

Mots-clés : Gouvernance transnationale du travail, effondrement de Rana Plaza, initiatives de sécurité transnationales, problèmes de distribution du travail, déréglementation néolibérale du travail

\section{Introduction}

The deadliest garment factory accident in human history occurred when Rana Plaza, an eight-story commercial building located in Savar, Bangladesh, collapsed killing approximately 1,134 ready-made garment (RMG) factory workers on 24 April 2013. ${ }^{1}$ Before its collapse, Rana Plaza illegally continued as a factory site with a politically influential building owner and economically powerful factory owners. The garment factories operating in Rana Plaza were either suppliers or sub-contractors to retailers or brands situated mostly in the industrialized countries of the North. ${ }^{2}$ Offering the lowest production cost, Bangladesh is an attractive sourcing choice for foreign brands/ retailers and ranks as the world's second-largest RMG supplier. ${ }^{3}$ Despite the fact that Bangladesh's RMG sector creates employment opportunities for millions and earns a huge export income, the tragic nature of the Rana Plaza collapse depicts the bitter reality of the globalized market and exploitative work conditions in the factories of developing countries and the loose contractual relationship between brand/retailers and low-skill labourers. While brands/retailers from all around the world enjoy the mobility of sourcing from the lowest-cost producers, and producing firms/suppliers enjoy government patronage (through favourable tax and investment policies), millions of impoverished garment workers-mostly women-work at rock-bottom wages, with poor or negative work entitlements, and put their lives and wellbeing at risk.

Considering this background, this article critically reviews some scholarly proposals for linking transnational labour governance (TLG) to trade/economic cooperation agreements or arrangements. ${ }^{4}$ It is claimed that if appropriately designed, these hybrid linkage mechanisms, with their region- or country-specific setting,

1 Jim Yardley, "Report on Deadly Factory Collapse in Bangladesh Finds Widespread Blame," New York Times, 23 May 2013. For an official number of final death toll from the Rana Plaza collapse see the Report of the Coordination Committee, Rana Plaza Arrangement, 8 June 2015. http://ranaplaza-arrangement.org.

2 Steven Greenhouse, “\$40 Million in Aid set for Bangladesh Garment Workers," New York Times, 23 December 2013.

3 Bangladesh's ready-made garments sector has exported goods worth US\$19.3 billion for 11 months that ended in May 2013. International Labour Organization (ILO), News Release, "ILO, Partners Aim to Improve Conditions in Bangladesh Garments Factory," 23 September 2013. www.ilo.org/ global/about-the-ilo/activities/all/WCMS_222019/lang--en/index.htm.

4 The literature on trade-labour linkage is enormous. Only three proposals are discussed in this article. See notes 38, 55, 65 below. For a recent discussion on linkage see Olivier De Schutter, Trade in the Service of Sustainable Development: Linking Trade to Labour Rights and Environmental Standards (Portland, Oregon: Hart Publishing, 2015). 
context-sensitive analysis, and capacity to improve domestic labour regulatory capacity, would provide important market-complementary interventions. These TLG mechanisms seek to lessen the pressures of a globalized market and address multiple problems of labour deregulation by monitoring factory-level working conditions, offering assistance to national governments to monitor compliance with national or international labour standards, and/or tying preferential market access to conditions to strengthen or improve domestic labour regulatory institutions.

This article suggests that despite rich theoretical analyses on the structural form or design of TLG mechanisms, less attention has been paid to the narrow conceptualizations of the social or distributional issues. ${ }^{5}$ While the concept of social or distributive justice covers wider issues such as allocation of resources, e.g., income, health, and education to weaker and marginalized/disadvantaged sections of society and assistance to displaced social groups, ${ }^{6}$ this article uses the term social to refer mostly to labour issues.

Section 1 briefly summarizes how these narrow conceptualizations of the social issues affected the bargaining capacity of labourers and reshaped the function of labour law. While political disempowerment of labour as a group and freedom of corporate sourcing thwarted the bargaining capacity of labour, only labourers with a formal contractual relationship enjoyed limited work entitlements and the protection of labour law. A large majority of labourers was left at the mercy of producing/ sourcing firms. Even the formal labourers became entitled to demand only fundamental labour rights and not the redistributive rights. The International Labour Organization's (ILO's) Declaration on Fundamental Principles and Rights at Work, adopted in 1998, commits member states to respect and promote four fundamental principles and rights at work: freedom of association, effective recognition of the right to collective bargaining, elimination of forced or compulsory labour and abolition of child labour, and elimination of discrimination in respect of employment and occupation. These ILO-prescribed rights widely referred to as core/fundamental labour rights do not include redistributive rights, i.e. minimum wages, work safety, maximum work hours, job security, unemployment benefits, etc. ${ }^{7}$

The restrictive form of labour governance gave rise to some distributional problems, i.e. existing labour laws offered limited benefits only for formal workers, downplayed collective action rights, emphasized voluntary forms of factory monitoring, and weakened the participation of non-state actors in the monitoring process.

Section 2 discusses three different types of scholarly proposals for linkage: linkage through corporate social responsibility (CSR); linkage through global institutional framework; and finally, linkage through social clause mechanisms (SCM) in bilateral/regional trade or economic cooperation agreements or arrangements. Most of these proposals focus on domestic labour regulatory problems, in that

Adelle Blackett and Christian Levesque, "Social regionalism in the global economy," in Social Regionalism in the Global Economy, ed. Adelle Blackett and Christian Levesque (New York: Routledge, 2011), 1.

6 Andrew Hurrell, "Global Inequality and International Institutions," Metaphilosophy 32, no. 1/2 (2001): 34-57.

7 ILO Declaration on Fundamental Principles and Rights at Work, (ILO, 1998). http://www.ilo.org/ declaration/lang--en/index.htm. 
they discuss how to improve the performance of domestic regulatory institutions. The distributional problems of labour and how these have contributed to labour deregulation remain largely unexplored in these analyses.

This article connects the theoretical analysis with some real-life examples. Referring to some of the challenges of labour governance in Bangladesh and the recent transnational safety initiatives (TSIs) ${ }^{8}$ taken to ensure safety of RMG workers after the collapse of Rana Plaza, ${ }^{9}$ this article posits that it is important to embrace a broader understanding of different rights of labourers and their conditions of work and bridge the existing gap between regulatory and distributional problems of labour.

\section{Narrow Conceptualizations of the Social and the Effects on Labour Governance}

After World War II, the market integration process ensured a "double movement" under which trade liberalization was accompanied by "social citizenship rights and social welfare entitlements, at least for the paradigmatic worker in the North." Influenced by Polanyi's sociological theory of market "embeddedness," ${ }^{11}$ Ruggie's famous "embedded liberalism" depicts this new form of state-market relationship where each state participating in the liberal market system reserved the power to determine its social policies and address social dislocations. ${ }^{12}$

At around the same time, international development and financial institutions (IDFIs), such as the World Bank and the International Monetary Fund became involved in designing the national development policies of the newly independent developing countries. During the 1990s, these institutions supported neo-liberal responses and prescribed a single and uniform template of rules and institutions with which to build market-based societies and achieve economic development. ${ }^{13}$

8 After the collapse of Rana Plaza, two non-corporate TSIs were launched, i.e. the ILO's Partnership Programme titled "Improving Working Conditions in the Ready-Made Garments (RMG) Sector," and the joint initiative of the EU and the Bangladesh government titled "Compact for Continuous Improvements in Labour Rights and Factory Safety in the Ready-Made Garment and Knitwear Industry in Bangladesh." For information on these non-corporate initiatives see, Improving Working Conditions in the Ready-Made Garment Sector in Bangladesh, (Geneva: ILO, 2013); Bangladesh: Protect Garment Workers' Rights, 6 February 2014, European Commission. This article mostly discusses two corporate initiatives involving brands/retailers mostly from North America and Europe. Member Agreement, Alliance for Bangladesh Worker Safety, 2013. www. bangladeshworkersafety.org [North American Alliance]; Accord on Fire and Building Safety in Bangladesh, 13 May 2013. www.bangladeshaccord.org [Accord].

9 This article does not elaborate upon the TSIs taken for Bangladeshi garment workers. A detailed analysis on TSIs is beyond its scope and can be found in Zobaida Khan, (2017), "Trade, labour and sustainable development: An integrated perspective,” DCL thesis, McGill University, Canada. Adelle Blackett, "Trade Liberalization, Labour Law and Development: A Contextualization," Discussion Paper Series No. 179 International Institute of Labour Studies 1 (2007).

11 Karl Polanyi, The Great Transformation: The Political and Economic Origins of Our Time (Beacon Hill, Boston: Beacon Press, 1944); Fred Block, "Karl Polanyi and the Writing of 'The Great Transformation," Theory \& Society 32, no. 3 (2003): 275-306.

12 John G. Ruggie, "International Regimes, Transactions, and Change: Embedded Liberalism in the Postwar Economic Order," International Organizations 36, no. 2 (1982): 379-415.

13 David M. Trubek and Alvaro Santos, "Introduction: The third moment in law and development theory and the emergence of a new critical practice, in The New Law and Economic Development: A Critical Appraisal, ed. David M. Trubek and Alvaro Santos (New York: Cambridge University Press, 2006), 1-18; Kerry Rittich, Recharacterizing Restructuring: Law, distribution and gender in market reform (The Hague, London: Kluwer Law International, 2002). 
Strict separation was maintained between the process of constructing appropriate legal rules and institutions to promote economic development objectives and the process of addressing social justice concerns. ${ }^{14}$ By erecting permanent barriers between questions of law and social justice, development and distributional policies, and market efficiency and social equity, neo-liberals promoted the neo-classical economic idea and suggested optimum allocation of resources to ensure efficiency in production. In the process of allocation of resources, they argued, it is not necessary to monitor the possible adverse impacts on different social groups. ${ }^{15}$ No space was left to address the tensions, failures, risks, or externalities arising from marketbased development. $^{16}$

The subordination of the social continued through neo-liberal assurances that adverse social/distributional consequences, if any, would be experienced for a short period of time, and in the long term, the "rising tide" of economic growth would lift "all boats." 17 When the neo-liberal prescriptions failed, the IDFIs adopted a revised development policy, which became popularly known as the "post-Washington consensus." ${ }^{18}$ Even though social justice was a goal to be attained within the reformed development policy, market-oriented rules and institutions shaped the "conceptual" meaning of the social and determined the process of attaining social goals. ${ }^{19}$ According to Rittich, this view created a particular framework for social concerns: these are "matters of politics" and would eventually be dealt with as a result of "spillover" benefits from economic growth. $^{20}$

These narrow conceptualizations prioritized the interests of capital owners and required that attention to labour issues be secondary. While at a national level neoliberal prescriptions suggested limited governmental intervention to develop effective regulatory institutions or finance public goods, at the international level trade liberalization and mobility of capital allowed corporations unconditional freedom to source from business-friendly locations where labour laws or their enforcement are relaxed. Connecting these multiple effects of globalization, it can be seen that labour deregulation is not simply a result of poor regulatory institutions in developing countries. Although internal political problems, corruption, and policy choices have contributed to poor labour governance in developing countries, five far-reaching effects can be identified from the narrow conceptualizations.

14 The discussion on isolation of the social or distributional issues borrows heavily from Rittich, Recharacterizing restructuring, 1-25, 153-169, and 283-291; David M. Trubek, "The 'Rule of Law' in Development Assistance: Past, Present, and Future," in Trubek and Santos (eds.), n. 13, 74-94; Kerry Rittich, "The Future of Law and Development: Second-Generation Reforms and the Incorporation of the Social," in Trubek and Santos (eds.), n. 13, 203-252.

15 Rittich, Recharacterizing Restructuring, 1-25, 153-169, 283-291.

16 Ibid.

17 Ibid. Steven Bernstein and Louis W. Pauly (eds.), Global Liberalism and Political Order: Towards a New Grand Compromise? (Albany: State University of New York Press 2007), 3-44.

18 For a discussion on the "post-Washington consensus" see Yuhiro Hayami, "From the Washington Consensus to the Post-Washington Consensus: Retrospect and Prospect," Asian Development Review 20, no. 2 (2003): 40-65.

19 Rittich, Recharacterizing Restructuring, 1-25, 153-169, 283-291; Judy Fudge, "The Cartography of Transnational Labour Law: Protection, scale and symbolism,” in Social Regionalism, n. 5, 299.

Rittich, ibid. 
First, a sharp division developed between fundamental and redistributive rights of labourers. Globalized production systems and unconditional mobility of capital gave rise to "market-centered model(s) of social inclusion and equality." Entitlements in the form of respect for fundamental rights were argued to provide the "entry point" for accessing the market. ${ }^{22}$ These generalized fundamental rights emphasize only the "[e]nabling rights that allow workers to associate together and to bargain collectively. There has been a shift away from the state imposition of substantive standards towards the provision of procedures enabling the parties to establish their own norms. This is part of a broader shift from government to governance or from hard to soft law, particularly in the realm of the social." ${ }^{23}$ These "core labour rights co-exist comfortably with the idea that rights of workers need not be enforceable entitlements, nor need labour be consulted in the design of market institutions." 24

These changes reshaped the function of labour law. Instead of limiting the market's capability to affect labour rights, labour law emphasized compliance with some fundamental rights. Discussions on redistributive functions of labour law are marginalized or ignored. ${ }^{25}$ No importance is placed on the mutually constitutive relationship between fundamental and redistributive rights in enhancing the dignity, wellbeing, and capability of labourers.

Second, unconditional mobility of capital caused significant changes in the bargaining capacity of labour. Constant fear stemming from capital's power to relocate to more hospitable places created an increased "risk of underbidding" by labourers. ${ }^{26}$ For many developing countries, where competitiveness is equated with low-cost labour, the primary question became not their workers' right to earn a living wage or to work in a safe workplace, but how to retain competitiveness and avoid allegations of "social dumping" of goods and products in countries with higher social standards. ${ }^{27}$

Third, a top-down formula of distribution developed. While most economic and trade literature promoted the idea that multilateral trade cooperation contributes to overall net economic gains, IDFIs prescribed that social/distributional

21 Fudge, “Cartography of Transnational Labour Law," 299-304.

22 Brian Langille, "Putting International Labour Law in the Right Map," in Social Regionalism, n. 5, 290-298; Steve Charnovitz, "The Labor Dimension of the Emerging Free Trade Area of the Americas," in Labor Rights as Human Rights, ed. P. Alston (Oxford: Oxford University Press, 2005), 143-176.

23 Fudge, "Cartography of Transnational Labour Law”, 304.

24 Kerry Rittich, "Core labour rights and labour market flexibility: two paths entwined," in Labour Law Beyond Borders: ADR and Internationalization of Labor Dispute Settlement, ed. International Bureau of the Permanent Court of Arbitration (The Hague: Kluwer Law International, 2003), 157-203, at 191.

25 Judy Fudge, “The New Discourse of Labour Rights: From Social to Fundamental Rights?" Comparative Labor Law \& Policy Journal 29, no. 1 (2007): 29.

26 Andreas Bieler, Ingemar Lindberg, and Devan Pillay, "The Future of the Global Working Class: An Introduction," in Labour and the Challenges of Globalization: What Prospects for Transnational Solidarity?, ed. Andreas Bieler, Ingemar Lindberg, and Devan Pillay (London: Pluto Press, 2008), 1-22; Andreas Bieler, Ingemar Lindberg, and Devan Pillay, "What Future Strategy for the Global Working Class? The need for a new historical subject," in Transnational Solidarity, 264-285.

27 For a critique on social dumping see Adelle Blackett, "Whither Social Clause: Human rights, Trade Theory and Treaty Interpretation," Columbia Human Rights Law Review 31 (1999): 1. 
concerns should be addressed at a national level and after economic growth has been achieved. ${ }^{28}$ Poverty was explained as the inability of developing states to adapt to the demands of market, and accordingly, policies were prescribed in order to improve their market participation capacity. ${ }^{29}$

Fourth, total or partial exclusion from the protection of labour law became the defining feature of the new "work relationships." 30 The portion of informal labourers (in developing countries) and the portion of labourers who fell outside labour law (in developed countries) grew at an exponential rate. Only formal labourers became entitled to receive the protection of labour law.

Fifth, an individualized approach to the enforcement of labour laws restricted or opposed the exercise of collective rights. According to Lord Wedderburn, "individualization" of labour rights explains why collective bargaining and industrial pressure at a transnational level were the most difficult activities. ${ }^{31}$ Only unionized formal labourers are allowed to take advantage of limited protections offered by national labour laws. As a result, no effective transnational labour class has emerged to confront the power and capacity of globalized production systems. $^{32}$

Without referring to the labour deregulation resulting from the narrow conceptualizations of the social, various proposals tried to link TLG with a trade or economic governance framework.

\section{A Critical Review of the Proposals for Linkage}

\subsection{Linkage through Cross-border Extension of CSR}

To minimize the power of capital to affect labour relations, some scholars proposed the cross-border extension of CSR to maintain minimum social rights in overseas production or supplier factories of multinational corporations (MNCs). ${ }^{33}$ Most CSR approaches, such as Sullivan principles, social partnership, and socially minimum standards, rely on non-binding corporate commitment for ensuring effective labour governance. Under Sullivan principles, home states of MNCs would oblige them to invest in countries that follow minimum social and environmental standards. ${ }^{34}$ The social partnership approach requires MNCs to follow CSR codes to improve the situations of their overseas employees. Socially minimum standards both for

28 Bernstein and Pauly, Liberalism and Political Order, 3-44.

29 Ibid.

30 Stone describes how structural changes in work relationships introduced flexibility in employment contracts and tied wages with market rate. Katherine Stone, "Rethinking Labour Law: Employment protection for boundaryless workers," in Boundaries and Frontiers of Labour Law: Goals and Means in the Regulation of Work, ed. Guy Davidov and Brian Langille (Portland: International Institute for Labour Studies, 2006), 155-180; Judy Fudge and Kendra Strauss, ed., Temporary Work, Agencies and Unfree Labour: Insecurity in the World of Work (New York: Routledge, 2013).

31 Lord Wedderburn, "Common Law, Labour Law and Global Law," in Social and Labour Rights in a Global Context, ed. Bob Hepple (Cambridge: Cambridge University Press, 2002), 19-54.

32 Bieler, Lindberg, and Pillay, "What Future Strategy for the Global Working Class?"

33 George DeMartino, Global Economy, Global Justice: Theoretical Objections and Policy Alternatives to Neoliberalism (London: Routledge, 2000), 190-215.

34 Due to transformation in production systems, MNCs are now outsourcing to distant and cheaper suppliers. Thus, the Sullivan approach is easily avoidable; Ibid. 
work entitlements and workplace conditions attempt to extend CSR to the supply chains of MNCs. ${ }^{35}$

However, as discussed in the previous section, the emphasis on voluntary and flexible CSR codes can be connected to the neo-liberal prescription on labour deregulation. Most CSR codes are not only unilaterally adopted, but also choose selective fundamental rights, avoid legal enforceability of redistributive rights, focus on voluntary monitoring, and are "limited in coverage," meaning that they apply only to the formal employees of a direct supply chain. ${ }^{36}$

Recent research suggests that CSR codes-when combined with robust approaches, such as the inclusion of non-state actors in factory monitoring, regularity in the monitoring process, and technological and organizational assistance to suppliers-could improve factory-level working condition ${ }^{37}$ and complement domestic labour regulation. ${ }^{38}$ Taking a cautious approach, Anne Trebilcock finds that it is difficult to monitor corporate compliance with due diligence, especially for ensuring collective labour rights or supply chain workers' rights. ${ }^{39}$ In a similar tone, Martin argues that although CSR codes have evolved by prescribing ILO standards, workers' collective action rights are significantly downplayed. ${ }^{40}$

Therefore despite its potential, CSR could be "used as a vehicle for a neo-liberal deregulatory agenda" and might promote a "technocratic" and "managerialist" type of "self-regulation" by powerful actors. ${ }^{41}$ Shamir argues, tellingly, that in some situations, CSR is used in a way that "diffuses its potentially radical application to MNCs" and "fits the hegemonic neoliberal framework." 42 For example, corporate freedom to relocate production or sourcing facilities creates "downward pressure"

Bieler, Lindberg, and Pillay, Transnational Solidarity, n. 26, 1-22, 264-285.

Bob Hepple, Labour Laws and Global Trade (Oxford: Hart Publishing, 2005).

Richard M. Locke, Fei Qin, and Alberto Brause, "Does Monitoring Improve Labor Standards: Lessons from Nike," Indiana Labour Relations Review 61, no. 1 (2007): 3-31; Kate Raworth and Anna Coryndon, Trading Away Our Rights: Women Working in Global Supply Chains (Oxford: Oxfam Publishing, 2004). At 58-63, the authors elaborate how employees are coached and paperwork is prepared prior to factory inspection.

38 Kevin Kolben, "Integrative Linkage: Combining Public and Private Regulatory Approaches in the Design of Trade and Labor Regimes," Harvard International Law Journal (2007) 48, Winter: 203257. At 231-234, Kolben illustrates the potential merits of private regulation and how these improve public regulatory system; Dara O’Rourke, "Multi-stakeholder Regulation: Privatizing or Socializing Global Labor Standards?” World Development 34, no. 5 (2006): 899-918.

39 Anne Trebilcock, "Due diligence on labour issues - Opportunities and limits of the UN Guiding Principles on Business and Human Rights," in Research Handbook on Transnational Labour Law, ed. Adelle Blackett and Anne Trebilcock (Cheltenham, UK: Edward Elgar Publishing, 2015), 93-110.

40 It is argued that with their ultimate objective to increase "shareholder value," the CSR mechanism prioritizes compliance with codes over the demands of local unions. Isabelle Martin, "Corporate Governance Structures and Practices: From ordeal to opportunities and challenges for transnational labour law," in Research Handbook on Transnational Labour Law, n. 39, 51-64.

41 Grainne de Burca, "New Governance and Experimentalism: An Introduction," Wisconsin Law Review (2010): 227-235. Although Burca analyzed the new and experimentalist type of governance mechanisms in general, the critiques apply to corporate monitoring as well. David Graham and Ngaire Woods, "Making Corporate Self-Regulation Effective in Developing Countries," World Development 34, no. 5 (2006): 868-883.

42 Ronen Shamir, "Corporate Social Responsibility: A Case of Hegemony and Counter-Hegemony," in Law and Globalization from Below: Towards a Cosmopolitan Legality, ed. B. De Souza Santos and C. A. Rodriguez-Garavito (Cambridge: Cambridge University Press, 2005), 92-117. 
on the already low labour standards in developing countries, ${ }^{43}$ and voluntary compliance with low-standard laws are deemed sufficient for doing business. It is alleged that some CSR codes are drafted without necessary inputs from labourers ${ }^{44}$ and might undermine the development of effective public labour regulatory systems. ${ }^{45}$ Also, factory monitoring with little or no participation from non-state actors or independence of auditors from the parent or sponsoring corporations raises significant doubts on the effectiveness of CSR.

Repeated factory accidents in Bangladesh vividly illustrate some of the limitations of CSR codes. Prior to the collapse of Rana Plaza, a fire at Tazreen fashions, another RMG factory in Dhaka, caused the death of approximately 112 factory workers who were trapped into a locked premise when the fire started. ${ }^{46}$ Some of the brands/retailers for whom the suppliers or sub-contractors were producing at Rana Plaza and Tazreen were subject to corporate codes or monitoring. Yet, none could stop forced work when fire alarms sounded at Tazreen or visible cracks appeared in the building columns of Rana Plaza. ${ }^{47}$ Some retailers and brands admit that inspections only cover factory-floor safety issues and do not cover the structural soundness of the factory building. ${ }^{48}$

At the collapsed building site, although labour rights activists found documents and garments of twenty-nine brands and retailers, initially only half of the companies with recent or current orders to five garment factories committed to contribute to the Rana Plaza compensation fund. ${ }^{49}$ Denying compensation, some reputed apparel brands questioned the existence of a formal relationship with the producing factories: one argued that there was "no formal contractual relationship" with the supplier and it was a "test" order; others argued that an unauthorized contractor was producing garments without their knowledge or no supply was due "at the time of collapse."

43 Ibid; Cesar A. Rodriguez-Garavito, "Nike's Law: The anti-sweatshop movement, transnational corporations, and the struggle over international labor rights in the Americas," in Law and Globalization from Below, p. 64.

44 Harry Arthurs, "Labor Law Without the State?" University of Toronto Law Journal 46, no. 1 (1996): 1-45; Harry Arthurs, "Private Ordering and Workers' Rights in the Global Economy: Corporate Codes of Conduct as a Regime of Labour Market Regulation," in Labour Law in an Era of Globalization, ed. Joanne Conaghan, Richard Michael Fischl, and Karl Klare (Oxford: Oxford University Press, 2002), 471.

45 Adelle Blackett, "Codes of corporate conduct and the labour regulatory state in developing countries," in Hard Choices, Soft Law: Voluntary Standards in Global Trade, Environment and Social Governance, ed. John J. Kirton and Michael J. Trebilcock (Aldershot, UK: Ashgate, 2004), 121-133.

46 Julfikar Ali Manik and Jim Yardley, "Bangladesh Finds Gross Negligence in Factory Fire," New York Times, 18 December 2012.

47 Rich Appelbaum and Nelsen Lichtenstein, "An Accident In history," New Labor Forum 23, no. 3 (2014): 58-65.

48 Syed Zain Al-Mahmood, Christina Passariello, and Preetika Rana, "The Global Garment Trail: From Bangladesh to a Mall Near You,” Wall Street Journal, 3 May 2013.

49 Greenhouse, "Aid for Bangladesh garment workers," n. 2; For a report detailing lack of commitment by some retailers to arrange funds for the victims of Rana Plaza, see Liana Foxvog, et al., Still Waiting: Six Months After History's Deadliest Apparel Industry Disaster, Workers Continue to Fight for Reparations (Amsterdam: Clean Clothes Campaign, 2013). At the time of writing this article, sufficient funds were available and already disbursed to the victims.

Greenhouse, "Aid for Bangladesh garment workers" above note 2. 
After the Rana Plaza collapse, two corporate safety initiatives, North American Alliance and Accord, ${ }^{51}$ attempted to cover fire and building safety for workers who have a formal employment relationship with the supplier companies. A narrow range of formal workers employed in 1,894 factories is covered out of the 5,000 to 6,000 garment factories in Bangladesh. ${ }^{52}$ Subcontractors, who do not have direct and formal contractual relationship with brands or retailers, are excluded from the coverage of these corporate initiatives.

Thus, the effectiveness of CSR in addressing the deeper consequences of labour deregulation remains questionable. How should independent and transparent monitoring throughout the supply chain be established ${ }^{53}$ If monitoring covers compliance with fundamental rights, what about redistributive rights? How to ensure that CSR reserves some space for enforcement of collective rights of workers? How far can legal responsibility be extended not only for direct suppliers, but also for those connected directly or indirectly with the supply chain? ${ }^{54}$ Recognizing the limitations of CSR, some scholars argue for labour governance through global institutional frameworks.

\subsection{Linkage through Institutional Frameworks}

Some linkage claims suggest that an effective global institution would delineate the appropriate relationship between market opening and labour governance and provide adequate threats or incentives to undertake necessary institutional reforms in developing countries.

\subsubsection{Reforming the World Trade Organization (WTO)}

Andrew Guzman proposes reforming the WTO by establishing two separate departments. ${ }^{55}$ A trade department would deal with purely trade issues and a labour department would oversee compliance with labour issues. ${ }^{56}$ While both departments would continue their functions on trade and labour issues respectively, neither would "negotiate agreements that bear directly on the other's area of

51 Member Agreement, Alliance for Bangladesh Worker Safety, 2013. www.bangladeshworkersafety. org [North American Alliance]; Accord on Fire and Building Safety in Bangladesh, 13 May 2013. www.bangladeshaccord.org [Accord].

52 The number of factories covered by the corporate TSIs is estimated in a recent report. See Sarah Labowitz and Dorothée Baumann-Pauly, Business as Usual is Not an Option: Supply Chains and Sourcing After Rana Plaza (New York University Stern School of Business, April 2014), 39. The current coverage extends to 2,225 factories. Some retailers have joined later and brought some more suppliers within the coverage of TSIs.

53 Pall A. Davidsson, "Legal Enforcement of Corporate Social Responsibility within the EU," Columbia Journal of European Law 8, no. 3 (2002): 529.

54 Recently, a California lawsuit alleges that although Costco Wholesale and its distributors do not "directly" allow use of slave labour in Thai shrimp farms, by procuring from these farms, Costco falsely represents that its sourcing practices are free from slavery and other gross violations of human rights. Erik Larson, "Costco Sued Over Claims Shrimp Harvested with Slave Labor," BloombergBusiness, 19 August 2015. Labour law scholars have explored the possibility of utilizing innovative legal techniques such as extending the definition of employer, employee, responsibility of "user" of labour to deal with the shortcomings or inabilities of existing labour law. See Davidov and Langille, ed., Regulation of Work, n. 30. However, despite conceptual promises, in reality, access to courts entails prohibitive costs and lengthy procedures.

55 Andrew T. Guzman, "Trade, labor and legitimacy," California Law Review 91, no. 3 (May 2003): 885.

56 Ibid. 
expertise." ${ }^{\text {57 }}$ Only during periodic mega rounds would these departments initiate "cross-issue talks" and discuss appropriate relationships between labour and trade, attempting to reach a political solution. During mega rounds, states in favour of linking labour-based exceptions to trade obligations would offer further concessions, such as WTO-plus market access. For Guzman, the long and complex process through mega rounds, though imperfect, is the "best" chance to reach a "negotiated, consensual agreement on trade and labour issue [s]" within the WTO. ${ }^{58}$

According to Guzman, the WTO's political body is a better forum to address linkage of trade and labour than the ILO, since the latter lacks an effective enforcement mechanism to address violations of labour rights. ${ }^{59}$ He discusses how the WTO can accommodate trade-based sanctions, though he acknowledges that the effectiveness of sanctions in improving labour conditions in a sanctioned state remains an open question. ${ }^{60}$ Without connecting the exiting labour governance problems with neo-liberal prescriptions, he focused on how social commitments of developing countries can be broadened and enforced through trade-based sanctions. ${ }^{61}$ He overlooked the fact that either by ratifying the ILO core conventions or entering into bilateral or regional trade agreements, most developing countries have already assumed broad social obligations. Thus it is not just the question of commitment to fundamental labour rights or their paper-based enforcement that matters for effective labour regulation; the deeper labour governance problems in developing countries need a holistic analysis. Bangladesh is an excellent example to prove this point.

The International Trade Union Confederation's (ITUC) report, prepared in 2012 and submitted to the WTO General Council, vividly describes the disparities between Bangladesh's formal international commitments and domestic labour rules and practices. ${ }^{62}$ Although Bangladesh has ratified thirty-five ILO conventions, including seven fundamental conventions, and adopted the "ILO Declaration on Fundamental Rights and Principles at Work," the report finds systematic violations of fundamental labour standards not only in practice, but also through existing rules. ${ }^{63}$ Therefore, it is much more important to focus on designing an effective "incentive-based" (not sanction-based) institutional framework that can realistically address labour governance problems in developing countries. ${ }^{64}$

\subsubsection{Reforming the WTO and the ILO}

Under Barry and Reddy's incentive-based institutional mechanism, developing countries would commit to improve existing labour governance in return for

\section{Ibid.}

Ibid., 901.

Ibid.

Ibid., 893 .

Ibid. At 893-894, Guzman briefly refers to other possible approaches to improve labour governance.

Internationally Recognized Core Labour Standards in Bangladesh: Report for the WTO General Council Review of the Trade Policies of Bangladesh (Geneva: International Trade Union Conference (ITUC), September 2012).

64 Chantal Thomas, “The WTO and Labor Rights: Strategies of linkage," in The World Trade Organization and Human Rights: Interdisciplinary Perspectives, ed. Sarah Joseph, David Kinley, and Jeff Waincymer (Northampton, MA: Edward Elgar, 2009), 257. 
developed countries' positive inducements, such as WTO-plus market access and burden-sharing arrangements to fund necessary improvements. ${ }^{65}$ According to Barry and Reddy, administration of the linkage system by a "rule-based" mechanism following "transparent, participatory and consensual" procedures would effectively address the problem of "opportunistic use" of social clauses in trade agreements. ${ }^{66}$ With the ability to impose sanctions as a measure of last resort and only for "egregious and systematic" violations of labour rights, the proposed mechanism would be more acceptable to the developing countries who oppose linkage for fear of protectionism. They suggest that one such possible system is to reform both the ILO and the WTO to form an "Agency for Trade and Labour Standards."

Barry and Reddy's proposal focuses on the form of linkage rather than the contents of labour rights. ${ }^{68}$ However, determining the form of linkage crucially depends on the labour rights that are intended to be protected. A focus on fundamental and redistributive rights would certainly entail a greater administrative and financial burden than a focus on fundamental rights only.

Their market-based linkage proposal focuses on improved labour governance through global financial assistance and monitoring and secures limited benefit for workers engaged with exporting firms. They do not explain what happens when exporting firms lose their competitive advantage. Broader issues like assistance to developing countries for retaining existing competitive advantages through improved labour skills or greater access to the "ideas" and "technologies" from MNCs or developed countries ${ }^{69}$ are not explored in their proposal. While it sounds too ambitious to consider such extended labour governance programs (including labour skill upgrading) through incentive based trade/economic agreements or arrangements, in a real-life scenario it is considered as one of the most efficient ways to prevent the race towards the bottom. ${ }^{70}$ The terms of trade for RMG products "are failing at around 2 percent a year" ${ }^{" 11}$ in Bangladesh. In order to maintain the existing competitive advantage in RMG manufacturing, the available options are either continuous lowering of production costs and labour entitlements or improvement of labour productivity. Without giving attention to the latter, it would be harder to sustain the improvements in labour governance.

According to Barry and Reddy, only with trade incentives is it possible to expect "action" in terms of financial commitment on the part of countries in the North

65 Christian Barry and Sanjay G. Reddy, International Trade \& Labor Standards: A Proposal for Linkage (New York: Columbia University Press, 2008).

66 Ibid.

67 Ibid.

68 Ibid., 153.

69 Roberto Unger, in his comments, raised the latter argument; ibid., 135-140.

70 Erik S. Reinert, "Emulation Versus Comparative Advantage: Competing and Complementary Policies in the History of Economic Policy," in Industrial Policy of Development: The Political Economy of Capabilities Accumulation, ed. Mario Cimoli, Giovanni Dosi, and Joseph E. Stiglitz (Oxford: Oxford University Press, 2009), 79; Bangladesh: Seeking Better Employment Conditions for Better Socioeconomic Outcomes, Studies on Growth and Equity (Geneva, Switzerland: International Labour Organization (ILO) and International Institute of Labour Studies (IILS), 2013).

71 ILO and IILS Study on Bangladesh, 2013, n. 70. For a comparative chart on falling terms of trade in the context of RMG, see Anu Muhammad, "Wealth and Deprivation: Ready-Made Garment Industries in Bangladesh," Economic \& Political Weekly XLVI (20 August 2011): 423-427, at 424; John Glenn, Globalization: North-South Perspectives (London: Routledge, 2007), 181. 
that are "sites of ownership, registration and management of firms."72 Without any powerful incentive such as the "ability to impose limitations on rights to trade," "it would be unfair to require Northern countries that do not actively participate in conduct that undermines labor standards to make net transfers to those that do...."73 Barry and Reddy do not explore whether the North would still be interested in joining and funding an international linkage system if, through expansive bilateral or regional trade agreements, they could require signatory developing countries to follow fundamental labour standards.

Barry and Reddy's argument that the North did not contribute to weakening of labour standards in developing countries remains a highly contested issue. Proposals for imposing minimum labour standards in developing countries have met counter-arguments, from global egalitarians, to adopting these with fair trade policies such as opening markets for developing countries' goods and products, significant fund transfers to address effective labour governance, and ensuring fairness in competition. ${ }^{74}$ It is argued that "sweatshop-labour" is itself a "product, at least in part, of decisions made over the decades by wealthier countries and consumers." 75 Overlooking these reasoned arguments of global egalitarians, their proposal focuses on finding fairness for the North's involvement in the global labour governance program and fails to explore the devastating outcome of neo-liberal prescriptions for developing countries, which are situated mostly in the South.

Finally, Barry and Reddy argue that increased market access and financial assistance from burden-sharing funds offers crucial incentives to secure the participation of developing countries in the linkage system. However, referring to Bangladesh's RMG sector it can safely be argued that financial commitments alone cannot address some of the distributional problems of labour. In Bangladesh, the "outsized" influence of RMG factory owners in the Parliament not only ensures enactment of favourable tax and necessary legislation, but also causes a delay in regulatory reforms on labour law and impedes proposals for "oversight" of this important export sector. ${ }^{76}$ Apart from the huge supply of unskilled workers, the political influence of the factory owners largely contributes to the prevalence of low wages and the negative entitlement of factory workers. Despite being the world's second largest RMG supplier, ${ }^{77}$ a Bangladeshi factory worker's average monthly

Barry and Reddy, Trade \& Labor, 45.

Ibid.

See Chris Armstrong, Global Distributive Justice: An Introduction (Cambridge: Cambridge University Press, 2012), 163-187. E. Kapstein, "Distributive Justice and International Trade," Ethics and International Affairs 13, no. 1 (1999): 175-204; D. Moellendorf, Global Inequality Matters (Basingstoke: Palgrave Macmillan, 2009), see the discussions in chapters 5 and 7 , from 90 and 132, respectively.

75 Armstrong, Global Distributive Justice.

76 Labowitz and Baumann-Pauly, "Sourcing after Rana Plaza," no. 52, 39; Dorothée Baumann-Pauly, Sarah Labowitz, and Nayantara Banerjee, Closing Governance Gaps in Bangladesh's Garment Industry - The Power and Limitations of Private Governance (Social Science Research Network, 12 March 2015); Jim Yardley, "Garment Trade Wields Power in Bangladesh,” New York Times, 24 July 2013; "Rags in the Ruins, A Tragedy Shows the Need for a Radical Improvement of Building Standards," The Economist, 4 May 2013.

77 ILO News Release, "ILO, Partners Aim to Improve Conditions in Bangladesh Garments Factory." 
wage continues to remain the lowest in the world and work conditions "have been amongst the worst in the global garments industry." ${ }^{\prime 8}$

It is true that effective monitoring by an independent and credible global institution, financial commitments, and strong domestic institutions would improve labour conditions and wages for a limited time period. However, in order to sustain the improvements in labour governance, it is necessary to connect these multidimensional governance challenges and track down the root causes of the disparities between capital and labour. Only through a context-based analysis of all these challenges, i.e. why and how the political disempowerment of labour started and how the bargaining capacity of labour decreased, is it possible to design and sustain an effective labour regulatory framework that would distribute the social gains from increased economic growth.

\subsection{Linkage through a Social Clause Mechanism (SCM)}

In trade or economic cooperation agreements, a SCM aims to establish a minimum floor of rights in signatory countries as a condition for preferential market access. Within the WTO, developing countries' fear of protectionism caused the demise of the proposal for inclusion of a SCM. ${ }^{79}$ In 1995, the ILO's Governing Council decided to suspend analyses on a SCM and the link between international trade and labour standards. ${ }^{80}$

Proponents of a SCM argue that regions possess both a distinctive understanding of social dislocations and a capacity to tailor a region-specific approach. ${ }^{81}$ As parties negotiate the terms of agreement, the prescribed standards are context-sensitive and monitoring compliance entails minimal cost. ${ }^{82}$ Also, compliance by exporting firms would eventually cause spillover benefits for non-exporting firms and improve the public labour regulatory system of the developing partner. ${ }^{83}$

Critics argue that a SCM prevents a "race towards the top" for fear of losing existing competitive advantage. ${ }^{84}$ In situations of non-compliance, sanctions might be used for political or protectionist purposes against trading partners with weaker social institutions. Hepple argues that until now, a sanction-based social clause has neither "effectively barred" products/services from low-standard countries, ${ }^{85}$ nor has it produced any positive result for their labourers.

Kevin Kolben suggests that the "state action-state sanction" model of linkage is "ill-suited to developing countries with dysfunctional regulatory regimes." ${ }^{86}$ Instead, an incentive-based SCM makes it easier to address specific problems of developing partners through "creative solutions." ${ }^{87}$ Kolben's trade incentive-based "integrative

ILO and IILS study on Bangladesh, 2013, n. 70.

Singapore Ministerial Declaration, 18 December 1996, WTO Document WT/MIN(96)/DEC.

Michael J. Trebilcock and Robert Howse, "Trade Policy \& Labor Standards," Minnesota Journal of Global Trade 14 (2004-2005): 262.

DeMartino, Global Economy, Global Justice, 190-215; Kolben, "Integrative Linkage," 246.

DeMartino, Global Economy, Global Justice, 190-215.

Kolben, "Integrative Linkage," 246.

DeMartino, Global Economy, Global Justice, 190-215, summarizes the critiques.

Hepple, Labour Laws.

Kolben, "Integrative Linkage," 205.

Kevin Kolben, "The WTO Distraction," Stanford Law and Policy Review 21 (2010): 461; Kolben,

"Integrative Linkage." 
linkage" (IL) accommodates a wider range of stakeholders than private labour regulatory mechanisms. ${ }^{88}$ Including representatives from unions, businesses, non-state actors, government, and employers, his proposed trade and labour governance council (TLGC) would design and direct the IL mechanism through master and regional/local councils. The TLGC would decide the form of monitoring and choose an independent monitoring body to ensure compliance with a mandatory set of standards. Kolben insists that the local councils under the TLGC might develop "novel forms of mediation that bring together all stakeholders, including multinational corporations that do business in that industry." ${ }^{89}$

As an example of his IL model, Kolben cites the ILO's Better Factories Cambodia programme. ${ }^{90}$ Under the US-Cambodia Textile Agreement, US offered Cambodian garment exporters an increased quota bonus over and above the regularly agreed-upon yearly quota bonus. In exchange, Cambodia agreed to improve work conditions in its garment factories and allowed the ILO to inspect factorylevel compliance with Cambodian labour law and international labour standards. The innovative features of the Better Factories Cambodia (such as, insistence on independent inspection through the ILO, public reporting on compliance, and tying Cambodia's participation in the program to preferential market access) caused a unique integration of public-private labour regulatory regimes. ${ }^{91}$

I agree with Kolben that, until now, the sanction-based social clause has only enriched the scholarly debates on linkage without producing any significant consensus at the political level. ${ }^{92}$ However, in Kolben's analysis, less attention has been given to some of the distributional problems of labour.

First, relying on Amartya Sen's capability theory, Kolben creatively links the expansion of labour freedom with effective institutional development. ${ }^{93}$ Yet, his IL model primarily emphasizes the ILO-prescribed fundamental labour rights. Although his proposed TLGC might include other labour rights or standards such as the right to a living wage, ${ }^{94}$ there is no emphasis on the integral connection between fundamental and redistributive rights of labour.

The Rana Plaza collapse bitterly exposes this integral connection. Factory workers were forced to enter and continue working in the Rana Plaza, even though large cracks were visible in its columns and warnings were in place to avoid any use of the building. ${ }^{95}$ Workers' power to have a voice against conditions of work depends largely on the presence of effective factory-level unions. In Bangladesh's RMG sector, there are "few factory-level organizations in the true sense of a trade union

\footnotetext{
Kolben, "Integrative Linkage."

Ibid., 253.

Kolben, "WTO Distraction."

Ibid.

Ibid.

Ibid., 466.

Kolben, "Integrative Linkage," 250-253.

Jim Yardley, "Report on Deadly Factory Collapse in Bangladesh Finds Widespread Blame," New York Times, 23 May 2013; Steven Greenhouse, "\$40 Million in Aid set for Bangladesh Garment Workers," New York Times, 23 December 2013.
} 
operation." 96 While the absence of real unions weakens the voice of labour to demand work entitlements or workplace safety, ${ }^{97}$ the absence of a living wage and other redistributive rights (such as maximum work hours and safe work conditions) ${ }^{98}$ suppresses the voice of labour by corrupting or intimidating union leaders and/or activists. ${ }^{99}$ A robust approach to labour governance thus requires not just a narrow focus on increased monitoring for formal workers of major exporting firms, but attention to the integral connections between the diverse rights of labour.

Second, for poor labour governance in developing countries, Kolben cites political and structural problems such as corruption, corporatist ties between the state, capital, and trade unions, and lesser allocation of government funds for labour ministries. ${ }^{100} \mathrm{He}$ finds that labour ministries are underfunded due to internal political choices such as the government's priority to create an attractive investment environment. ${ }^{101}$ His analysis of labour regulatory problems in developing countries places little emphasis on the disruptive influence of neo-liberal prescriptions in developing countries.

In Bangladesh, the political marginalization of labour started with the adoption of neo-liberal reforms towards the end of 1980s. International development and financial institutions' prescribed institutional reforms changed both the capacity of union-based labour movements and government's labour regulatory priorities; while union movements became highly "fractionalized," demands for improved work conditions and wages became sporadic and unorganized, receiving limited political attention. ${ }^{102}$ Upholding neo-liberal economic prescriptions, two bitterly divided political parties compete for power, emphasizing privatization, export-led growth, and trade liberalization. Neither has any substantial pro-labour agenda and, consequently, the labour ministry is under-funded. A weak regulatory capacity for labour governance in Bangladesh can be connected more with the "marginalization from current political settlement" than with the problem of resources. ${ }^{103}$ Political disempowerment of labour and government's minimal interest in effective labour regulation are reflected through the imbalanced ratio of inspectors to the number of factories. Despite having a $4.8 \%$ share in global clothing export, until

96 Faisal Ahmed, Anne Greenleaf, and Audrey Sacks, “The Paradox of Export Growth in Areas of Weak Governance: The Case of the Ready-Made Garment Sector in Bangladesh, World Development 56 (2014): 258.

97 Lance Compa, “After Bangladesh, Labor Unions Can Save Lives," Washington Post, 26 May 2013.

98 Prior to the collapse of Rana Plaza, average monthly income of an RMG worker in Bangladesh was US\$43. According to a 2011 report of the Fair Labor Association, a worker living alone in Dhaka requires US\$75-82 and US\$164 for maintaining a family per month. See Wages Along the Supply Chain: Trends, Progress and Looking Ahead (Washington: Fair Labor Association, 2011).

99 Julfikar Ali Manik and Vikas Bajaj, "Killing of Bangladeshi Labor Organizer Signals an Escalation in Violence," New York Times, 4 October 2012. Kolben, "WTO distraction," 483-484.

101 Ibid.

102 Muhammad argues that the neo-liberal reforms intended to "create a large pool of labour: disorganized, scattered, unable to assert its rights and forced to accept low wages" (Muhammad, "Wealth \& Deprivation," n. 71, 23-24); Anu Muhammad, "Globalization and Economic Transformation in a Peripheral Economy, the Bangladesh Experience," Economic \& Political Weekly 41, no. 15 (April 2006): 1459-1464.

103 Ahmed, Greenleaf, and Sacks, "Paradox of Export Growth"; Muhammad, "Wealth \& Deprivation"; Muhammad, "Bangladesh Experience." 
the collapse of Rana Plaza, there were only 18 inspectors for 5,000 to 6,000 garment factories in Dhaka. ${ }^{104}$

Third, Kolben finds that independent monitoring would generate information on compliance and, with such information, not only can consumers and businesses determine their buying and sourcing policies, but also NGOs, unions, and activists can pressure local employers and regulators to improve working conditions. ${ }^{105}$ According to Kolben, while a factory-level performance comparison would pressure a race to the top, a comparative evaluation of public regulatory systems of trading partners would "potentially lead to greater regional integration in labor standards."106 In Kolben's IL model, the emphasis is not on businesses' responsibility to adopt an ethical sourcing strategy, but on their capacity to choose compliant producers or suppliers. The inevitable connection between corporate sourcing policies and poor working conditions in the factories of developing countries is not prioritized in his analysis. ${ }^{107}$

Recently, under one of the corporate initiatives, the Accord, the signatory brands and retailers from over twenty countries in Europe, North America, Asia, and Australia committed to maintaining a long-term sourcing relationship and to negotiating contractual terms and pricing in a manner that would render it financially feasible for the suppliers to maintain a safe workplace and undertake necessary upgrades or remediation. ${ }^{108}$ This "ethical" pricing policy attests to the essential relationship between labour conditions and corporate sourcing policies and practices.

104 ILO and IILS study on Bangladesh, 2013, n. 70; OECD, Global Forum on Responsible Business Conduct, Summary Report (Paris, France: OECD, 26-27 June 2013); Ahmed, Greenleaf, and Sacks, "Paradox of Export Growth." For factory level inspection, a separate department of inspection for factories and establishments was created in 1970 in the then East Pakistan. The inspection department specifically endorses Article 3 of the ILO convention no. 81 regarding "Labour Inspection" in Industry and Commerce. Department of Labour, Ministry of Labour and Employment, Government of Bangladesh. www.mole.gov.bd. After the collapse of Rana Plaza, the ILO aims to appoint 200 labour and factory inspectors by the end of 2013 and a total of 800 inspectors within 2014. In March 2015 the total number of inspectors became 276 and inspection service has been upgraded into a directorate with its annual budget and necessary infrastructure. ILO, "Rana Plaza, Two Years On: Progress Made and Challenges Ahead for Bangladesh RMG Sector," 21 April 2015, 6-8. www.ilo.org/global/about-the-ilo/media-centre/press-releases/ WCMS_229135/lang-en/index.htm. Kolben, "Integrative Linkage," 247.

106 Ibid., 250.

107 For a detailed discussion on how "upstream" sourcing practices of retailers and brands (downward pressure on prices, volatility, and instability in orders) cause "downstream" problems (indirect sourcing, low wages, exploitation of migrants and contingent workers), see Mark Anner, "Workers' Power in Global Value Chains: Fighting Sweatshop Practices at Russell, Nike and Knights Apparel," in Transnational Trade Unionism: Building Union Power, ed. Peter Fairbrother, Marc-Antonin Hennebert, and Christian Leveque (London: Routledge, 2013), 23-41; Mark Anner, Jennifer Bair, and Jeremy Blasi, “Toward Joint Liability In Global Supply Chains: Addressing The Root Causes of Labor Violations in International Subcontracting Networks," Comparative Labour Law and Policy Journal 35, no. 1 (2013): 1; Locke, Qin, and Brause, "Lessons from Nike"; Tugce Bulut and Christel Lane, "The Private Regulation of Labour Standards and Rights in the Global clothing Industry: An Evaluation of its Effectiveness in Two Developing Countries" New Political Economy 16, no. 1 (February 2011): 41-71; Mark Anner and Jakir Hossain, "Multinational Corporations and Economic Inequality in the Global South: Causes, Consequences, and Countermeasures," (paper delivered at the $9^{\text {th }}$ Global Labour University Conference, Berlin, 15-17 May 2014.

Accord, n. 8 at section 23. 
It is necessary to connect the bargaining imbalances between labour and capital with the neo-liberal prescriptions. In accordance with the advice of IDFIs, national governments paved the way for doing business, privatized socio-economic responsibilities, and deregulated capital and financial markets. This allowed corporations unconditional freedom to transfer production facilities or to source from businessfriendly locations where labour laws or their enforcement are relaxed. An effective TLG system should analyze these multi-dimensional effects of neo-liberal prescriptions in a holistic manner and not just rely on corporations' goodwill to choose compliant sourcing factories.

Fourth, Kolben agrees that the monitoring under his IL model would cover only workers employed in major export industries that experience the "greatest rise in exports due to tariff liberalization." ${ }^{109}$ Kolben argues that the stakeholders in his IL model would eventually address the question of protecting labour in informal or non-export sectors. ${ }^{110}$ What happens if indirect sourcing is a "routine" business practice of major exporting suppliers? ${ }^{111}$ What happens if brands/retailers have de facto knowledge of the use of subcontractors? In a recent article, BaumannPauly, Labowitz, and Banerjee describe how indirect sourcing by Bangladeshi RMG suppliers is regularly tolerated by brands/retailers despite their written policy of zero tolerance for illegal sub-contracting. ${ }^{112}$

As mentioned earlier, both corporate TSIs, North American Alliance and Accord, cover only the workers who have a formal contractual relationship with supplier companies. Though brands/retailers do not directly employ these low-cost and low-entitlement workers or allow unauthorized subcontracting, a connection exists between their high margin of profit and the use of these workers in their supply chains. There is evidence that most brands/retailers have de facto knowledge of their suppliers' inability (in terms of number of machines and employees) to meet their large orders and their need to resort to the use of subcontractors. Yet they avoid direct contractual relationships with subcontractors in order to manage fewer contracts and still profit more from the lower price of bigger orders. ${ }^{113}$

Thus despite the promises of the SCM, with emphasis on formal workers engaged by exporting firms and focus on multifaceted issues such as competition, investment, and intellectual property rights, in real-life these arrangements promote labour issues as a "secondary" concern. ${ }^{114}$ The developing trading partners also appreciate limited attention to labour issues. The asymmetries between trade and labour agenda are reflected through the "means" used to enforce them; while trade opening is ensured through "hard" means, labour issues are addressed with "soft"

Kolben, "Integrative Linkage", 247.

Kolben, "Integrative Linkage," 256.

Labowitz and Baumann-Pauly, Sourcing after Rana Plaza, n. 52.

Baumann-Pauly, Labowitz, and Banerjee, Closing Governance Gaps, n. 76.

Vikas Bajaj, "Doing Business in Bangladesh,” New York Times, 14 September 2013.

Jan Orbie, Myriam Gistelinck, and Bart Kerremans, "The Social Dimension of European Union Trade Policies," in The European Union and the Social Dimension of Globalization: How the EU Influences the World, ed. Jan Orbie and Lisa Tortell (London: Routledge, 2009), 148-165 at 158 . 
means. ${ }^{115}$ It is found that the EU's bilateral trade treaties are mostly satisfied with dialogue-based cooperative mechanisms for improving labour standards of trading partners. $^{116}$

Deeper and broader redistributive questions, such as what social issues need to be addressed and who would be covered and how, remain on the periphery. ${ }^{117}$ The "activist" and "robust" focus on market access without the necessary adjustment mechanisms being implemented at a bilateral or regional level "weakens nascent social integration in developing states." 118

Therefore, any discussion on linkage should not focus only on the presence of a monitoring programme or the improvement of regulatory institutions that inspect compliance with national and international laws and standards. An effective linkage mechanism should cover broader redistributive questions, including the capacity of the developing partner(s) to design and fund an appropriate labour regulatory framework and connect labour governance with overall trade, economic, and redistributive policies. According to Kolben, "[i]t remains unclear ... how much Cambodia's regulatory capacity has grown [despite better monitoring]." ${ }^{\prime 19}$ In a more recent publication, Kolben also argues for a "deeper market analysis" by the developed trading partner(s) to understand country-specific "structural organization" of labour market and impacts of trade liberalization, rather than taking a "formalistic, legal compliance oriented approach" to enforce labour rights. ${ }^{120}$

\section{Concluding Analysis}

It is possible to extract some common features from the above-mentioned linkage proposals. Most scholars find that addressing the problems of poor regulatory institutions and low level of enforcement is the route to ensure effective labour governance in developing countries. Without connecting the existing disparities between developing and developed countries with regard to institutional development and capacity to offer social protection, the suggested mechanisms prefer effective monitoring or regulation. Discussions on neo-liberal policy prescriptions and governments' minimum interest in labour regulation, the inherent connection between fundamental and redistributive rights of labour, the conditions of a semi-formal or informal workforce supplying to the exporting firms, and the connection between corporate sourcing policies and practices and poor work conditions do not receive any priority. Also, the prescribed mechanisms focus primarily on labourers engaged in exporting firms; improving labour skill and productivity or

115 Jan Orbie and Lisa Tortell, "From Social Clause to the Social Dimension of Globalization," in The European Union and the Social Dimension of Globalization, 1-26.

116 Werner Raza, "European Union Trade Politics: Pursuit of Neo-Mercantilism in Different Fora," in Strategic Arena Switching in International Trade Negotiations, ed. Wolfgang Blass and Joachim Becker (Aldershot, UK: Ashgate, 2007), 67-96; Orbie, Gistelinck, and Kerremans, "Social Dimension of EU Trade Policies," 1-26.

117 Diamond Ashiagbor, "Embedding Trade Liberalization in Social Policy: Lessons from the European Union?” Comparative Labour Law and Policy Journal 32, no. 2 (2011): 373.

118 Ibid.

119 Kolben, “Integrative Linkage," 242.

120 Kevin Kolben, “Trade, Development, and Migrant Garments Workers in Jordan," Middle East Law \& Governance 5 (2013): 195-226. 
the importance of retaining existing competitive advantages for major exporting sector(s) of a developing country are not prioritized in these linkage proposals.

Particularly referring to some real-life challenges of Bangladesh's RMG sector and the TSIs taken to improve labour governance, this article argues that, in order to design an effective TLG mechanism, the starting point should be a deeper and contextual analysis of the interconnected labour problems. It is necessary to consider the process of trade liberalization, the outcome of neo-liberal prescriptions, and the consequences of existing labour deregulation in a holistic frame. The suggestions of the IDFIs regarding the privatization of social responsibility, the deregulation of financial and capital markets, and reduced government spending for public institutions were different from the trade liberalization process undertaken as a result of accession to the GATT/WTO. ${ }^{121}$ Yet due to the aggregate effect of promoting a liberalized market, corporate sourcing freedom, and reduced government spending on public goods, most low-income developing countries have experienced increasing levels of social inequities and poor human development despite increased trading. ${ }^{122}$ Without giving appropriate attention to the root causes of these social disparities and labour deregulation and how these have created/aggravated the distributional problems of labour, the existing narrow focus on the structural form of linkage (such as CSR codes or global institutional monitoring or SCM) will not necessarily improve poor labour governance in developing countries, let alone develop the social institutions necessary to withstand the challenges of market integration.

Existing discussions on the structural form of linkage are important. Yet the incompatibility between the power and mobility of capital with vulnerability and immobility of labour at a global level creates a situation in which the pursuit of a redistributive agenda, through voluntary monitoring or through offering limited rights for formal workers, becomes questionable. An effective and sustainable labour governance through trade or economic agreements or arrangements needs to be viewed in the overall context of net economic benefits that a developing trading partner would receive (i.e., whether appropriate funds would be generated for improving the labour regulatory framework and undertaking broad redistributive programs), ${ }^{123}$ the labour regulatory framework (covering labourers in sectors that would experience export growth), and social/redistributive policies (covering labourers dislocated due to trade opening). Any discussion on linkage of "the social into the economic" ${ }^{124}$ thus requires a careful and detailed analysis of who

121 General Agreement on Tariffs and Trade, 30 October 1947, entered into force 1 January, 1948, 58 UNTS 187. GATT, 1994 adopted the provisions of GATT, 1947 and was included as Annex 1A of the Marrakesh Agreement Establishing the World Trade Organization, 1994, 1867 UNTS 154 WTO. https://www.wto.org/english/docs_e/legal_e/04-wto_e.htm. [Referred to as "GATT"]. Shamsul Haque, “The Fate of Sustainable Development Under Neo-liberal Regimes in Developing Countries," International Political Science Review 20, no. 2 (1999): 197.

123 Professor Trebilcock argued that some provisions of bilateral trading agreements might significantly disadvantage established economic sectors of smaller developing partners. Michael Trebilcock, "Response to Kevin Kolben on Bilateralism, Trade Preferences, and Market Abuse," Middle East Law \& Governance 5 (2013): 227.

124 Adelle Blackett, "Towards Social Regionalism in the Americas," Comparative Labour Law and Policy Journal 23, no. 4 (2002): 901-966 at 905. 
(what development model is to be pursued), what (which labour rights are to be protected), and how. For example:

a. A development model that prioritizes market-based growth would only focus on monitoring and governance at exporting firms. On the other hand, attention to building a strong redistributive mechanism would focus on effective governance of formal, semi-formal, and informal labourers. The coverage of the latter is wider and enables us to focus beyond the economic empowerment of a narrow range of formal workers or voluntary forms of corporate responsibility. The broader mechanism realizes that improved labour governance does not routinely result from increased monitoring but starts by addressing the distributional problems that contribute to the uneven allocation of resources and power between workers and firms.

b. The protection of fundamental labour rights only entails a limited cost and offers limited and short-term benefit. On the other hand, if we consider that the protection of workplace entitlements, the economic and political empowerment of labour, and the strengthening of regulatory institutions are essentially interconnected, then a long-term and sustainable commitment on labour governance would be required.

c. Thirdly, it is important to consider how to realize these interconnected labour rights-how to fund and mobilize the development of necessary institutions and formulate necessary social/redistributive policies. ${ }^{125}$ For example, in the case of bilateral or multilateral trade agreements or arrangements, it is necessary to consider the detailed framework of the governance of labourers who would be displaced due to trade opening.

Without a coherent and context-specific analysis of these interrelated issues, labour groups disadvantaged by market integration or disconnected from formal export sectors can expect very little from any linkage mechanism.

Zobaida Khan

Faculty of Law, McGill University

zobaida.khan@mail.mcgill.ca

zk0209@gmail.com

125 An elaborate discussion on these issues is beyond the scope of this critical review. I address these issues in one of my papers titled "Rethinking post Rana-Plaza transnational labour governance: A proposal for transformative linkage," under review. 